\section{Marine Biology}

June 2008, Volume 154, Number 4 : Pages 671-682

http://dx.doi.org/10.1007/s00227-008-0960-9

(C) Springer-Verlag 2008

The original publication is available at http://www.springerlink.com
Archimer, archive institutionnelle de l'fremer http://www.ifremer.fr/docelec/

\title{
Bacterivory of a mudflat nematode community under different environmental conditions
}

\author{
Pierre-Yves Pascall ${ }^{1,{ }^{*}}$, Christine Dupuy ${ }^{1}$, Pierre Richard $^{1}$, Jadwiga Rzeznik-Orignac ${ }^{2}$, Nathalie Niquil $^{1}$ \\ ${ }^{1}$ Littoral, Environnement et Sociétés (LIENSS) UMR 6250 CNRS-Université de La Rochelle, 2 Rue Olympe de \\ Gouges, 17042 La Rochelle cedex, France \\ ${ }^{2}$ Biologie des organismes marins et écosystèmes (BOME) UMR-CNRS 5178-USM 0401- MNHN, 61 Rue \\ Buffon, 75231 Paris, France \\ *: Corresponding author : Pascal P. Y., email address : pypascal@univ-Ir.fr
}

\begin{abstract}
:
The fate of the benthic bacterial biomass is a topic of major importance in understanding how softbottom environments function. Because of their high abundance, production and nutritional value, benthic bacteria may constitute an important food resource for benthic fauna. The trophic role of bacteria for a nematode community on the Brouage mudflat (Marennes-Ole'ron-France), dominated by three species: Chromadora macrolaima (64\% of the abundance), Daptonema oxycerca (15\%) and Ptycholaimellus jacobi (8\%), was determined in grazing experiments using ${ }^{15} \mathrm{~N}$ pre-enriched bacteria. On intertidal flats, seasonal, tidal and circadian cycles induce strong variations in environmental conditions. Grazing experiments were performed in order to measure the effects of abiotic (temperature, salinity and luminosity) and biotic (bacterial and algal abundances) factors on assimilation rates of bacteria by nematodes. In order to assess simultaneously bacteria and algal assimilation rates, algal abundances were modified adding ${ }^{13} \mathrm{C}$ pre-enriched Navicula phyllepta. Assimilation rate was significantly lower at $5^{\circ} \mathrm{C}$; moreover, general trend shows a prominent temperature effect with an optimum around $30^{\circ} \mathrm{C}$. Assimilation at salinity 18 was not significantly different from the assimilation at salinity 31 . Assimilation was higher under light conditions than in the dark. Above $10^{9}$ bacteria $\mathrm{ml}^{-1}$, assimilation of bacteria remained unaffected by bacterial abundance. However, assimilation of algae increased with the algal concentration. Nematode kept feeding under conditions of stress, which are typical of the surficial sediment habitat and they appeared to be principally dependent on the algal resource.
\end{abstract}

Keywords: Nematode, bacteria, grazing, environmental factor, mudflat 


\section{Introduction}

Bacteria play a major role in cycling organic matter in marine sediments through the remineralization of nutrients and organic matter and production of particulate and dissolved carbon (e.g. Legendre and Rassoulzadegan 1996; Rivkin et al. 1996). Although bacterial abundance remains stable, around 109 cells $\mathrm{ml}-1$ (review in Schmidt et al. 1998), bacterial production rates vary greatly (Sander and Kalff 1993). This discrepancy between abundance and production may be induced by bottom-up, biochemical and top-down control (van Oevelen et al. 2006a). In the top-down control situation, bacterial carbon is assumed to be regulated by higher trophic levels of benthic food webs. The majority of animals feeding on sedimentary deposits are more dependent on attached bacteria than on nonliving organic debris (e. g. Fenchel 1972). Models of benthic ecosystems emphasize the role of bacteria and their immediate grazers as a major route through which organic material is processed (e. g. Kuipers et al. 1981). Consequently, quantitative data dealing with the link between bacteria and benthic fauna are essential for understanding the extent to which this trophic link structures energy and material fluxes in the communities. Results concerning the impact of meiofaunal grazing on bacteria are conflicting (Kemp 1990). Montagna (1984b) suggested that meiofaunal grazing pressure (principally through 
49 these environmental variations: long-term (seasonal cycle), medium-term (lunar cycle) and

polychaetes) represents a significant stimulatory effect on the microbial community and may be important in sandy sediments (Montagna and Bauer 1988). However, quantitative studies on meiobenthos bacterivory are sparse.

Although they are small and inconspicuous, nematodes are consistently the most abundant meiobenthic taxon in mudflat sediments. Their average densities of $10^{6}$ ind $\mathrm{m}^{-2}$ represents a biomass of roughly 0.2 to $2 \mathrm{gC} \mathrm{m}^{-2}$ and some authors have suggested that their ecological significance is great in terms of food-web relationships (review in Platt and Warwick 1980; Heip et al. 1985).

Benthic bacteria can constitute a significant food source for nematodes (Lopez et al. 1979; Tietjen 1980; Montagna 1984b; Montagna 1995; Moens et al. 1999b). According to Wieser (1960), there are four different feeding groups of nematodes: selective deposit feeders (1A), non-selective deposit feeders (1B), epigrowth feeders (2A) and omnivore-predators (2B). Nematodes of each feeding groups are potential bacterivores, even predacious may benefit directly from bacterial carbon (Moens et al. 1999b). Deposit and epigrowth feeders feed on bacteria and unicellular eukaryotes in different ways. Deposit-feeding species have no teeth and generally swallow the food whole and undamaged. They feed predominantly on bacteria associated with detritus. The epigrowth feeding species puncture the cell membrane with their teeth and ingest only the cell contents (juice feeders). Diatoms and other benthic microalgae are known to be important trophic sources for many epigrowth feeders but the importance of bacteria as a food source remains poorly documented (Moens and Vincx 1997). The aim of this study was to experimentally assess rates of bacteria uptake by a nematode community from an intertidal mudflat using ${ }^{15} \mathrm{~N}$ enriched bacteria as tracers. The intertidal habitat studied is subject to a wide range of environmental varying factors. Three relevant time scales drive short-term (solar and tidal cycles) (Guarini et al. 1997). Variations concern both biotic (i.e. 
74 temperature, salinity and luminosity) and abiotic factors (i.e. bacterial and algal abundances).

75 As those variations may influence the feeding behavior of nematodes, one aim of the present study is to determine if nematodes bacterivory is constant in the mudflat or influenced by environmental factors. Other aim is to describe feeding behavior of nematodes when an alternative algal resource is available.

For this purpose, a mudflat nematode community from surficial sediment was put in microcosms, in contact with labeled preys: a bacterial community and one algal species.

81 Grazing experiments were performed in order to evaluate effects of abiotic (temperature, salinity and luminosity) and biotic (bacterial and algal abundances) factors on rates of prey uptake. We focused on the surficial mudflat sediment nematode community because the surficial sediment (i) has high bacterial production, (ii) contains the highest nematodes densities and (iii) undergoes faster and more wide-ranging changes in environmental factors than do the deeper layers.

\section{Material and methods}

Study site

The Brouage intertidal mudflat is located in the eastern part of the Marennes-Oléron Bay (Atlantic coast of France). Meteorological conditions exhibit a strong seasonality typical of a

91 temperate climate. Temperature and salinity of emerged sediments are more extreme during summer tidal cycles (Guarini et al. 1997). Minimum and maximum mud temperatures are $5^{\circ} \mathrm{C}$ and $34^{\circ} \mathrm{C}$ respectively. The maximum daily range of mud temperature due to emersion and immersion cycle reaches $18^{\circ} \mathrm{C}$ (Guarini et al. 1997). Salinity of overlaying water is controlled

95 by the river Charente freshwater input, ranging from 25 to 35 over the year (Héral et al. 1982). Salinity of the upper layers of sediment may also decrease with rainfall. The sediment

97 surface irradiance shifts from dark during submersion and night emersions to high levels of

98 incident light during daytime emersions. This irradiance can reach $2000 \mu \mathrm{M}$ of photons $\mathrm{m}^{-2} \mathrm{~s}^{-1}$ 
99 (Underwood and Kromkamp 2000). Details of numerous benthic organisms and processes are

100 available concerning this intertidal zone (gathered in Leguerrier et al. 2003; Leguerrier et al.

101 2004; Degré et al. 2006).

\section{${ }^{15} \mathrm{~N}$ enriched bacteria and ${ }^{13} \mathrm{C}$ enriched algae as tracer}

The method used was described in Pascal et al. (2008). This method is based on the assumption that grazers ingest unselectively enriched and natural bacteria. Briefly, one centimeter-depth of surficial sediment was sampled during ebb tide in the Brouage mudflat $\left(45^{\circ} 55 \mathrm{~N}, 1^{\circ} 06 \mathrm{~W}\right)$ (Fig. 1). Bacteria from surficial sediment were cultured in a liquid bacterial culture medium containing ${ }^{15} \mathrm{NH}_{4} \mathrm{Cl} 1 \mathrm{~g} \mathrm{l}^{-1}\left(99 \%{ }^{15} \mathrm{~N}\right.$-enriched $\mathrm{NH}_{4} \mathrm{Cl}$ CortecNet), rinsed by centrifugation and frozen until the grazing experiments. An axenic clone of the Navicula phyllepta diatom (CCY 9804, Netherlands Institute of Ecology NIOO-KNAW, Yerseke, The Netherlands) was cultured in a liquid medium containing $\mathrm{NaH}^{13} \mathrm{CO}_{3}$, then rinsed and freeze111 dried until the grazing experiments. Isotopic composition of enriched prey was assessed using mass spectrometer. For these experiments, labeled preys were mixed with sediment from the

113 Brouage mudflat that had been previously sieved through a $50 \mu \mathrm{m}$ mesh. The abundance of

114 bacteria and algae in the slurry was estimated in order to determine the ratio between enriched 115 and unenriched prey.

Grazing experiments

117 The top centimeter of sediment was collected on March 13, 2006. At the time of sampling, 118 sediment presented a temperature of $7^{\circ} \mathrm{C}$ and a salinity of 29 . Sediment sampled was first 119 sieved through a $500 \mu \mathrm{m}$ mesh to remove macrofauna, then through a $50 \mu \mathrm{m}$ mesh to extract 120 meiofauna. One $\mathrm{ml}$ of the sediment remaining in the mesh was put into each microcosm 121 (Pyrex beakers, $\varnothing=4.5 \mathrm{~cm}$ ) and the fraction which passed through the mesh was mixed with ${ }^{15} \mathrm{~N}$ enriched bacteria. This slurry contained $10.5 \times 10^{8}$ bacteria $\mathrm{ml}^{-1}$, with the ${ }^{15} \mathrm{~N}$ enriched bacteria being twice as abundant as unenriched ones. Four $\mathrm{ml}$ of this slurry were put into each 
124 microcosm. Each experiment was carried out in triplicate. Control samples were frozen ($12580^{\circ} \mathrm{C}$ ) in order to kill any nematodes.

126 A kinetic study was performed to validate its linear or hyperbolic shape in order to 127 calculate the grazing rate. Incubations for this kinetic study were run for 1 to 12 hours, 128 including the 3 hours run that was used for all other experiments. Incubations were made 129 under the following standardized conditions that were close to the year-round mean values 130 recorded on the study site: temperature $\left(20^{\circ} \mathrm{C}\right)$, salinity $(31)$, luminosity (darkness), bacterial 131 abundance $\left(10.5 \times 10^{8}\right.$ bacterial cell $\left.\mathrm{ml}^{-1}\right)$ and algal abundance $\left(15 \mu \mathrm{gChla} \mathrm{g}^{-1}\right)$.

132 For each other experiment one environmental incubation factor was modified. In order to 133 decrease salinity, cultured bacteria were rinsed with $0.2 \mu \mathrm{m}$ filtered-sea-water diluted with 0.2 $134 \mu \mathrm{m}$ filtered water (final salinity of 18). The light effect was tested with a light intensity of 83 $135 \mu \mathrm{M}$ photons $\mathrm{m}^{-2} \mathrm{~s}^{-1}$. Bacterial abundances (total enriched and non-enriched) tested were 4, 7 136 and 17 cells $\mathrm{ml}$ wt sed-1 with respectively the following ratio between abundance of total and 137 enriched bacteria: 6.1, 2.0 and 1.3. Algal abundance was modified by adding various 138 quantities of cultured N. phyllepta enriched in ${ }^{13} \mathrm{C}$ while bacterial abundances (total enriched

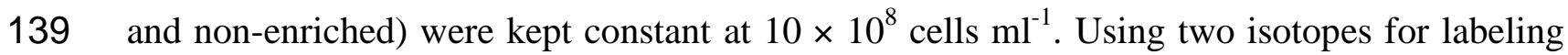
140 bacterial $\left({ }^{15} \mathrm{~N}\right)$ and algal food $\left({ }^{13} \mathrm{C}\right)$ offers the opportunity to assess bacterial and algal 141 ingestion rates simultaneously. Algal abundance (total enriched and non-enriched) were 26, 14264 and $114 \mu \mathrm{gChla} g$ dry $\operatorname{sed}^{-1}$ with respectively the following ratio between abundance of 143 total and enriched algae: 2.4, 1.3 and 1.2.

144 Incubations were halted by freezing the microcosms at $-80^{\circ} \mathrm{C}$. Samples were thawed and 145 nematodes were extracted from the sediment using Ludox TM (Heip et al. 1985). For each 146 sample, at least 700 nematode specimens were picked up randomly and individually with 147 Pasteur pipette, rinsed twice in Milli-Q water to remove adhering particle and transferred in 148 aluminium cup. 


\section{Isotope analysis and calculations}

$\delta^{15} \mathrm{~N}$ and $\delta^{13} \mathrm{C}$ of prey (bacteria and algae) and grazers (nematodes) were measured using an EA-IRMS (Isoprime, Micromass, UK). Nitrogen isotope composition is expressed in the delta notation $\left(\delta^{15} \mathrm{~N}\right)$ relative to air $\left.\mathrm{N}_{2}: \delta^{15} \mathrm{~N}=\left[\left({ }^{15} \mathrm{~N} /{ }^{14} \mathrm{~N}\right)_{\text {sample }} /\left({ }^{15} \mathrm{~N} /{ }^{14} \mathrm{~N}\right)_{\text {reference }}\right)-1\right] \times 1000$. Carbon isotope composition is expressed in the delta notation $\left({ }^{13} \mathrm{C}\right)$ relative to Vienna Pee Dee Belemnite (VPDB): $\left.\delta^{13} \mathrm{C}=\left[\left({ }^{13} \mathrm{C} /{ }^{12} \mathrm{C}\right)_{\text {sample }} /\left({ }^{13} \mathrm{C} /{ }^{12} \mathrm{C}\right)_{\text {reference }}\right)-1\right] \times 1000$.

The ${ }^{15} \mathrm{~N}$ incorporated was defined as excess (above the background level) ${ }^{15} \mathrm{~N}$ and is expressed in terms of specific uptake $(I) . I$ was calculated as the product of excess ${ }^{15} \mathrm{~N}(E)$ and the biomass of N per grazer. $E$ is the difference between the background ( $\left.F_{\text {background }}\right)$ and the sample $\left(F_{\text {sample }}\right){ }^{15} \mathrm{~N}$ fraction: $E=F_{\text {sample }}-F_{\text {background }}$, with $F={ }^{15} \mathrm{~N} /\left({ }^{15} \mathrm{~N}+{ }^{14} \mathrm{~N}\right)=R /(R+2)$ and $R=$ the nitrogen isotope ratio. For the $F_{\text {background, }}$ we used highest control values $\left(\Delta^{15} \mathrm{~N}=\right.$ 11.78 and $\Delta^{13} \mathrm{C}=-16.34$ ) measured using killed (frozen) grazers. $R$ was derived from the measured $\delta^{15} \mathrm{~N}$ values as: $R=\left(\left(\delta^{15} \mathrm{~N} / 1000\right)+1\right) \times R \operatorname{airN}_{2}$ where $R$ airN ${ }_{2}=7.3529310^{-3}$ (Mariotti 1982). The uptake of bacterial carbon was calculated as Uptake $=\left(I \times\left(\% \mathrm{C}_{\text {enriched }}\right.\right.$ bacteria $\left./ \% \mathrm{~N}_{\text {enriched bacteria }}\right) /\left(F_{\text {enriched bacteria }} \times\right.$ incubation time $)$. This uptake was multiplied by the ratio between the abundance of total and enriched bacteria determined by DAPI counts.

Incorporation of ${ }^{13} \mathrm{C}$ was calculated analogously, with $F={ }^{13} \mathrm{C} /\left({ }^{13} \mathrm{C}+{ }^{12} \mathrm{C}\right)=R /(R+1)$, $R$ airN $N_{2}$ is replaced by $R_{\mathrm{VPDB}}=0.0112372$ and Uptake $=I /\left(F_{\text {enriched bacteria }} \times\right.$ incubation time $)$. The uptake measured was multiplied by the ratio between the abundance of total and enriched diatom, determined from fluorometrical measurements.

Enriched N. phyllepta-produced carbon consisted of $22.95 \pm 0.54 \%{ }^{13} \mathrm{C}$. The $\mathrm{C} / \mathrm{N}$ ratio of enriched bacteria was 3.49 and bacterial nitrogen consisted of $2.88 \pm 0.03 \%{ }^{15} \mathrm{~N}$. The average weight of nematodes was $0.33 \pm 0.18 \mu \mathrm{g}$ DW and each nematode was composed on average of $0.11 \pm 0.05 \mu \mathrm{gC}$ and $22.28 \pm 5.82 \mathrm{ngN}(\mathrm{N}=72$ samples of at least 700 specimens each $)$. 
173 Uptake expressed as $\mathrm{gC}_{\text {bacteria }} \mathrm{gC}_{\text {nematode }}{ }^{-1} \mathrm{~h}^{-1}$ was obtained by dividing the uptake of bacteria

$174\left(\mathrm{gC} \mathrm{ind}^{-1} \mathrm{~h}^{-1}\right)$ by the mean nematode weight $\left(\mathrm{gC} \mathrm{ind}^{-1}\right)$.

175 Variations of assimilation rates with respect to the salinity and luminosity were tested

176 using two-tailed test. One-way analysis of variance (ANOVA) was used in order to test the

177 impact of temperature and algal and bacterial abundance on the uptake rates of bacteria and

178 algae. The Tukey test was used for post-hoc comparisons.

179

180

181

182

183

184 1960).

Nematode community composition

Nematode communities used in the grazing experiments were extracted from sediment with Ludox TM (Heip et al. 1985). In order to determine the taxonomic composition of the community studied, 303 nematodes were collected at random, determined to species or generic level under the microscope and sorted by feeding group as indicated by Wieser (1953;

\section{Results}

Composition of the nematode community

In the sample collected for the taxonomy of the nematode community, 19 species belonging to 18 genera were observed (Tab. 1). Three species made up more than $87 \%$ of the community: Chromadora macrolaima (64\%), Daptonema oxycerca (15\%) and Ptycholaimellus jacobi (8\%). The other species were much less abundant, 11 representing less than $1 \%$.

192 The community was dominated by epigrowth feeders $2 \mathrm{~A}(75 \%)$ due to high abundances of C. macrolaima and P. jacobi. Non-selective deposit feeders 1B (21\%) were the second most abundant trophic group due to high abundance of D. oxycerca. Selective deposit feeders $1 \mathrm{~A}$ 195 (2\%) and omnivores/predators 2B (1\%) exhibited marginal abundances in the community studied. 
Nematodes isotopic compositions and rates of bacterial ad algal uptakes are presented in Table 2.

The kinetic experiment showed that bacterial uptake by the nematode community 201 increased linearly during the twelve hours of incubation (Fig. 2). The linear regression slope 202 suggested an assimilation rate of bacteria of $32 \mathrm{pgC} \mathrm{ind}^{-1} \mathrm{~h}^{-1}$ equivalent to $25 \times 10^{-5} \mathrm{gC}_{\text {bacteria }}$ $203 \mathrm{gC}_{\text {nematode }}{ }^{-1} \mathrm{~h}^{-1}\left(\mathrm{r}^{2}=0.98\right)$.

204 Temperature had a significant effect on the assimilation rate of bacteria $(F=7.5, \mathrm{p}<0.005)$.

205 Temperature tested fluctuated between 5 and $40^{\circ} \mathrm{C}$ and were in the range of those found in the 206 study area (Guarini et al. 1997). Uptake of bacteria was reduced at $5^{\circ} \mathrm{C}$, then increased with 207 temperature to reach an optimum at around $30^{\circ} \mathrm{C}$ and then decreased (Fig. 3). This rate 208 increased from $3 \mathrm{pgC}$ ind $^{-1} \mathrm{~h}^{-1}$ to $25 \mathrm{pgC}$ ind $^{-1} \mathrm{~h}^{-1}$ when the temperature rose from $5^{\circ} \mathrm{C}$ to $20930^{\circ} \mathrm{C}$ and then decreased, reaching $18 \mathrm{pgC} \mathrm{ind}^{-1} \mathrm{~h}^{-1}$ at $40^{\circ} \mathrm{C}$. Overall trend is showing a 210 prominent temperature effect but assimilation rates observed at $10,20,30$ and $40^{\circ} \mathrm{C}$ were 211 nevertheless not significantly different from each other but were significantly different from 212 those observed at $5^{\circ} \mathrm{C}$.

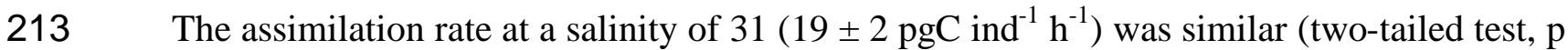
$214=0.72)$ to that found for a salinity of $18\left(18 \pm 4 \mathrm{pgC} \mathrm{ind}^{-1} \mathrm{~h}^{-1}\right)$ (data not shown).

215 Light significantly affects the feeding activity of nematodes (two-tailed test, $\mathrm{p}<0.05$ ).

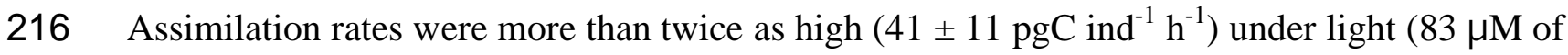

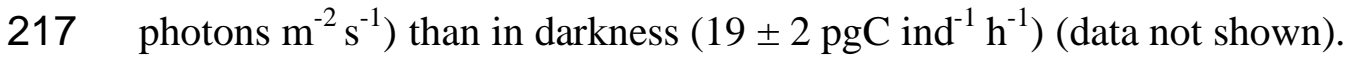

218 Assimilation rates were significantly linked with bacterial abundance $(F=52, \mathrm{p}<0.001)$ 219 (Fig. 4). Its value was null for the lowest tested abundance $\left(4 \times 10^{8}\right.$ cells $\left.\mathrm{ml}^{-1}\right)$, was amplified

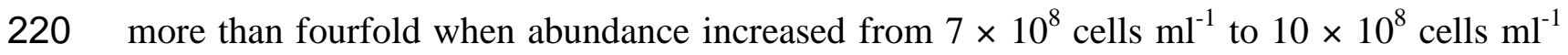
221 and remained stable between this last value and $17 \times 10^{8}$ cells $\mathrm{ml}^{-1}$. 
Using two isotopes to label bacterial $\left({ }^{15} \mathrm{~N}\right)$ and algal food $\left({ }^{13} \mathrm{C}\right)$ offers the opportunity to assess bacterial and algal uptake rates simultaneously. Assimilation of algae increased linearly when algal abundance increased $\left(\mathrm{r}^{2}=0.99, \mathrm{p}<0.05\right)$. Bacteria represented 25,16 and $8 \%$ of algal plus bacterial intake when algal concentrations were respectively 26,64 and $114 \mu$ gChla $\mathrm{g}^{-1}$, with bacterial abundance remaining constant (Fig. 6). Plotted data indicated that assimilation of bacteria declines when the algal concentration is high $\left(114 \mu \mathrm{gChla} \mathrm{g} \mathrm{g}^{-1}\right)$ and the bacterial concentration remains constant (Fig. 5). Nevertheless, these differences were not significant and assimilation of bacteria was unaffected by algal abundance $(\mathrm{F}=3.24, \mathrm{p}=$ $0.11)$.

\section{Discussion}

\section{Nematode community}

Rzeznik-Orignac et al. (2003) studied the Brouage mudflat nematode community and showed that in the lower part of the mudflat and over four seasons (2000-2001), six dominant species represented $45 \%$ of the community: Metachromadoroides remanei (11.5\%), Terschellingia longicaudata (11.2\%), P. jacobi (8.6\%), C. macrolaima (8.6\%), Sabatiera pulchra (5.2\%) and D. oxycerca (0.7\%). In our study, performed in March 2006, only three species, although all mentioned in the Rzeznik-Orignac et al. study, represented $87 \%$ of the community (Tab. 1). As the sampling site was the same, difference in nematode community composition may be due to inter-seasons or inter-years fluctuations. More probably, major

241 difference has to be put into relation with the sampling method used in each of these studies.

242 In the present one, only the top centimeter of sediment was sampled, whereas the top $5 \mathrm{~cm}$ 243 were sampled in the Rzeznik-Orignac et al. (2003) study. As nematodes exhibit a strong 244 vertical distribution of species in sediment (e. g. Platt 1977; Steyaert et al. 2001), the 245 community in the present study is not representative of the total Brouage mudflat nematode community. Moreover, the three major species of the community under study belong to the 
247 Daptonema and Ptycholaimellus genera that were mainly found in the $5 \mathrm{~mm}$ surficial layer of

248 sediment (Steyaert et al. 2003) and the third one, belonging to the family Chromadoridae is a 249 typical surface-dwelling epigrowth feeder (Platt 1977).

250 Feeding habits on diatoms of some genera close to Chromadara are known from culture 251 experiments: Chromadorita tenuis (Jensen 1987) and Chromadora macrolaimoides (Tietjen 252 and Lee 1973). Chromadora macrolaima and Ptycholaimellus jacobi break or pierce the 253 frustule of diatoms to suck out their contents whereas Daptonema oxycerca swallow the 254 whole diatom cell (Wieser 1953; Wieser 1960). Our nematode community is mainly 255 composed by three dominant species known or suspected to feed predominantly on diatoms. 256 The entire nematode community presents however higher abundances of bacterial grazers 257 (Rzeznik-Orignac et al. 2003). As a result, extrapolation of the present grazing results to the 258 rest of the community or to other communities must be realized with caution.

$259 \quad$ Grazing experiments

260 Like all various methods previously developed and applied to measure bacterivory, the 261 method used in the present study presents methodological shortcomings that make 262 interpretation of the resulting problematic. For instance, sieving the sediment changes the 263 bacterial availability, bacteria being not attached to particle as in natural situation. Indeed, 264 disruption of microbial-meiofaunal spatial relationships is known to affect grazing rate with 265 slurry method (Carman et al. 1989). Nematode grazing can be highly dependent on their 266 bacterial prey's activity, size and species (Tietjen et al. 1970; Tietjen and Lee 1973; Romeyn 267 and Bouwman 1983; Grewal and Wright 1992; Moens 1999; Moens et al. 1999a). One major 268 hypothesis in grazing experiments is that grazers did not select for or against the added 269 labeled bacteria over the bacteria present in the sediments. Consequently, the cultured bacteria 270 community must present characteristics that are roughly similar to the natural one. Despite the 271 fact that our culturing process modified the specific composition of the natural bacterial 
272 community, the size, activity and diversity of the bacterial consortium used in the present

273 study would be more representative of the natural community than in most previous grazing 274 experiments (Pascal et al. 2008).

\section{$275 \quad$ Bacterial and algal uptake}

$276{ }^{15} \mathrm{~N}$ accumulation in nematodes was linear over the 12-hour incubation period (Fig. 2). The 277 constant accumulation of labeled food in nematodes had already been observed with 278 comparable incubation times (Herman and Vranken 1988; Moens et al. 1999c). Since the 279 nematode defecation intervals are very short (e. g. Thomas 1989) and since the gut is emptied 280 completely with each defecation (Duncan et al. 1974), the gut contents would thus be renewed 281 every few minutes. For these reasons, it has been suggested that during long incubation times, 282 the linear accumulation of the label indicates assimilation rather than ingestion (Schiemer 283 1987; Moens et al. 1999c). The slope of this linear curve gives an assimilation rate of $32 \mathrm{pgC}$ 284 ind $^{-1} \mathrm{~h}^{-1}$. Assuming an assimilation rate of 25\% (Herman and Vranken 1988; Somerfield et al. 285 2005), the ingestion rate would be four times higher, at $128 \mathrm{pgC} \mathrm{ind}^{-1} \mathrm{~h}^{-1}$. As all other grazing 286 experiments were run for 3 hours, they provided the assimilation rate of food.

$287 \quad$ Abiotic factors

288 Behavioral responses of plant-parasites and terrestrial nematodes to several stimuli such as 289 electrical, mechanical and chemical stimuli and physical factors such as temperature and light 290 have been well described (review in Croll 1970). However, similar studies concerning the 291 effect of environmental conditions on the feeding behavior of marine or brackish-water 292 nematodes are scarce and limited in scope.

293 Temperature has received attention as a factor influencing the growth and reproduction of 294 estuarine and marine nematodes (review in Heip et al. 1985). The influence of temperature on 295 feeding has only been studied in the predacious nematode Enoploides (Moens et al. 2000), the 296 epigrowth feeder Chromadora macrolaimoides (Tietjen and Lee 1973) and in two brackish- 
water bacterivorous species: Pellioditis marina and Diplolaimelloides meyli (Moens et al.

298 1996; Moens and Vincx 2000). In the present study, nematodes exhibited a classical response 299 which was more or less related to a bell-shaped function also observed by Moens and Vincx 300 (2000). The assimilation rate of bacteria rose when the temperature increased and reached its 301 upper value at $30^{\circ} \mathrm{C}$ before declining. As assimilation rates recorded for the tested 302 temperatures were statistically different at $5^{\circ} \mathrm{C}$, it may be suggested that the nematode grazing 303 rate is lower in winter when the temperature drops to under $5^{\circ} \mathrm{C}$. However, nematodes may 304 adjust their optimum temperature conditions along seasons (Gee 1985). Studied nematodes were probably adapted to low temperature as sediment temperature was $7^{\circ} \mathrm{C}$ at the time of the sampling. Montagna (1984b) did not observe different grazing rates between winter and 307 summer, but the temperature range in his study area was small (18 and $\left.23^{\circ} \mathrm{C}\right)$.

308 Salinity plays a major role in determining the spatial structure of the nematode community 309 along permanent gradients (Soetaert et al. 1995) or in its seasonal variations (Chatterji et al. 1995). However nematodes can also be affected by short-term variations in salinity (Forster 311 1998) and intertidal habitats are subject to major changes in interstitial salinity over short time 312 periods. During low tide, raindrops implode into fine sediments, disturbing and mixing the 313 surface sediment of mudflats. Moreover, freshwater run-off passively diffuses into the 314 interstitial pores of the sediment. In their review of marine nematode ecology, Heip et al. 315 (1985) compiled an extensive list of marine and estuarine species with their salinity 316 tolerances. C. macrolaima, the most abundant species in the present study, is found in areas 317 with salinities ranging from 35 to 24 whereas $D$. oxycerca, the second most abundant species, 318 is found in area ranging from 35 to 0.9 . This species seemed to be able to tolerate gradual 319 changes in salinity but not rapid ones. After exposure to salinity of 3.33 for $10 \mathrm{~min}$ and $48 \mathrm{~h}$, 320 Forster (1998) recorded adult mortalities of 10-35\% and 70\% respectively. This species from 321 the lower level of the intertidal zone is able to osmoregulate but unable to sustain water 
regulation over long periods (Forster 1998). In the present study, assimilation at salinity 18 was not significantly different from the assimilation at salinity 31 . Since the nematodes were not acclimated until the grazing experiment, they seemed to be able to cope with rapid, but limited, osmotic stress. Our conclusions concerning the minor role of salinity in bacterial assimilation by nematodes are in accordance with Moens and Vincx's (2000) results. Among the three factors they investigated (temperature, salinity and food abundance) affecting $P$. marina and $D$. meyli food intake, salinity played a minor role in bacterial assimilation by nematodes.

When exposed to air at low tide, benthic organisms at the sediment's surface are subject to 331 the highest solar and UVB radiation that can be experienced by marine organisms. There are 332 few investigations assessing the effects of luminosity on nematodes. The predacious 333 nematode Enoploides caught approximately twice as many prey nematodes in the dark as in 334 light (Moens et al. 2000). On the other hand, Sundbäck et al. (1996a) concluded that ambient 335 UVBs did not exert any strong selective pressure on the meiofaunal community of a muddy 336 microtidal area. Nozais et al. (1999) observed a deleterious effect of UVBs on the nauplia 337 stages of harpacticoid copepods from a tidal mudflat. However, they did not observe any 338 effect on nematode abundance. In our study, light may not present damaging effect as 339 nematodes fed actively, moreover bacterial assimilation was enhanced when light increased.

340 Uptake rates of bacteria by foraminifera (Pascal et al. In press) and the gastropoda Hydrobia 341 ulvae (Pascal et al., in prep) that were obtained by grazing experiments performed under the 342 same conditions as in present study did not demonstrate any effect of light. Consequently, the 343 response we observed should not be due to experimental bias and seems to be specific to 344 nematodes. Montagna et al. (1995) observed a significant correlation between algal 345 production and the grazing rate of a nematode community from the Brouage mudflat. In their 346 experience, algal production was increased by increasing the light intensity above 
347 microcosms. They concluded that nematode's ingestion rate increases with algal production.

348 In intertidal mudflats, benthic diatoms migrate in the surface sediment along the diurnal cycle

349 (e. g. Serôdio et al. 1997). The nematode community under study was dominated by 350 epigrowth feeders (Tab. 1), with a diet mainly composed of benthic diatoms. Those 351 nematodes may graze when luminosity is high during low tide in order to graze in algal 352 biofilm and maximize their algal intake. This feeding behavior has not been documented for 353 nematodes, but harpaticoid copepods were shown to graze at a higher rate just after the 354 mudflat became exposed (Decho 1988). Buffan-Dubau and Carman (2000) also observed a 355 midday feeding peak by ostracods and harpaticoid copepods. This result suggests that 356 nematodes would have a feeding behavior principally controlled by algae and that bacteria 357 may be taken up accidentally with algae.

\section{$358 \quad$ Biotic factors}

359 For nematodes, the effects of bacterial concentration on growth, fecundity, population 360 development and feeding rates have been studied (Nicholas et al. 1973; Schiemer et al. 1980; 361 Schiemer 1982a; Schiemer 1982b; Schiemer 1983; Vranken et al. 1988; Moens and Vincx 362 2000). Nematode ingestion rates are generally proportional to food availability (Nicholas et 363 al. 1973; Schiemer et al. 1980; Moens et al. 1996). However, the relationship between 364 assimilation rate and food concentration is not linear and have been described by a Michaelis365 Menten function (Schiemer 1982b). This function is consistent with Holling's prey-dependent 366 type II functional response (Holling 1959). Assimilation rates depend on the amount of 367 ingested food and efficiency with which the material is assimilated. The assimilation 368 efficiency have been found to decrease when food concentration increases: at a high food 369 concentration Plectus palustris presented a low assimilation efficiency (12\%) (Duncan et al. 370 1974) whereas at a food concentration one order of magnitude lower, the assimilation 371 efficiency reached 57\% (Schiemer et al. 1980). A similar conclusion was drawn by Moens et 
372 al. (2006) on the marine bacterivore Pellioditis marina. Low efficiencies at high

373 concentrations appear to result from short gut retention times, with the gut transit being too

374 fast for effective digestion (Taghon et al. 1978). In the present study, it is not possible to

375 determine if assimilation rates fluctuations are due to variations of ingestion rates or 376 assimilation efficiencies. The number of bacterial concentrations tested was limited, however

377 the response observed could be described by a sigmoid function. This function is consistent 378 with Holling's prey-dependent type III functional response (Holling 1959). The threshold 379 value for significant assimilation appeared to fall between 4 and $7 \times 10^{8}$ cells $\mathrm{ml}^{-1}$ and the

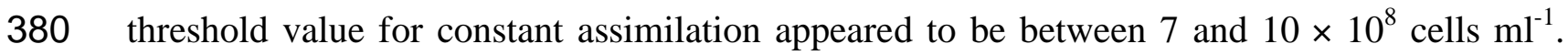

381 Those values are in the range of data provided by literature for fast growing opportunistic 382 bacterivores nematodes typical of plant material or root systems: an optimal grazing rate was 383 obtained for Caenorhabditis briggsae (Nicholas et al. 1973) and P. marina and D. meyli 384 (Moens and Vincx 2000) at a bacterial concentration of 5, 25 and $5 \times 10^{8}$ cells ml $^{-1}$ 385 respectively. Our study, dealing with tidal flat microalgal grazers community, suggests that 386 the optimal level of bacterial foraging is also reached at high bacterial density, when bacterial 387 concentrations attain $1 \times 10^{9}$ cells ml $^{-1}$. As bacterial concentrations are rarely lower in marine 388 sediments, (Hondeveld et al. 1992; Schmidt et al. 1998; Hamels et al. 2004), bacterial

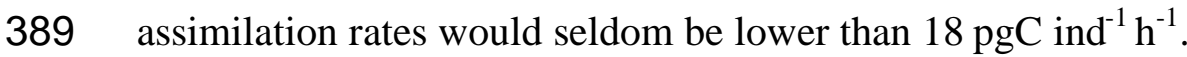

390 The relationship between the assimilation rate of algae and the algal concentration is 391 poorly documented. Montagna et al. (1995) observed a proportional rise in the algal grazing 392 rate with increasing algal concentration. In the present study, algal assimilation increased 393 linearly without reaching a plateau. This function may be consistent with Holling's prey394 dependent type I functional response (Holling 1959). Thus, the algal concentration threshold 395 was not reached and maximal algal assimilation may be higher than those we obtained. Under natural conditions, the chlorophyll a content of the first centimeter of sediment varies between 
3970 and $50 \mu \mathrm{gChla} \mathrm{g}^{-1}$ (review in MacIntyre et al. 1996). However, through vertical migration,

398 benthic microalgae were concentrated near the surface during diurnal low tides and produced

399 a biofilm with an average thickness of $50 \mu \mathrm{m}$ (Herlory et al. 2004). In this thin layer of algal

400 mat, the concentration of chlorophyll a can reach $150 \mu \mathrm{gChla} \mathrm{g}{ }^{-1}$ (Serôdio et al. 1997) and

401 even $300 \mu \mathrm{gChla} \mathrm{g}^{-1}$ (Kelly et al. 2001). Thus, the higher algae abundance used in the present

402 study (114 $\left.\mu \mathrm{gChla} \mathrm{g}^{-1}\right)$ is not representative of conditions occurring in the natural

403 environment and the nematode community feeding on the algal biofilm could thus present a

404 higher assimilation rate of algae.

405 In our experiment, algal assimilation by nematodes always represented more than three 406 times the bacterial assimilation. Nematodes are able to select potential food items. 407 Chromadora macrolaimoides have a preference for diatoms and chlorophytes whereas they 408 assimilate fewer bacteria (Tietjen and Lee 1973). D. oxycerca is able to swallow particles of 409 different sizes and large frustules of diatoms (Boucher 1974). The three dominant species of

410 the community studied, i.e. C. macrolaima, D. oxycerca and P. jacobi, were found to 411 dominate the Brouage nematode community during spring diatom blooms (Rzeznik-Orignac 412 et al. 2003) indicating that they are highly dependent on algal resources. The use of natural 413 stable isotopic analyses led to a similar conclusion elsewhere, that the microphytobenthos 414 constitutes the main food source for the nematode community dwelling in the surficial 415 centimeter of mud in the study area (Riera et al. 1996). Montagna et al. (1984b), looking at 416 the grazing rates of a nematode community from a saltmarsh, found that diatoms are selected 41714 more times than bacteria. Algal carbon accounted on average for more than $90 \%$ of carbon 418 grazed by a nematode community from a microtidal sandy sediment (Sundbäck et al. 1996b). 419 In the present study, nematodes also ingested algae at a higher rate than bacteria. Depending 420 on the algal concentration, the nematode community assimilates 3 to 11 times more diatoms 421 than bacteria. 
Nematode production can be estimated on the basis of the $\mathrm{P} / \mathrm{B}$ ratio, bearing in mind that

423 the choice of this ratio may be inaccurate (Heip et al. 1982). With an individual biomass of $0.11 \mu \mathrm{gC}$ ind $^{-1}$, the estimation of production yielded $0.11 \mathrm{ngC} \mathrm{ind}^{-1} \mathrm{~h}^{-1}$, given a $\mathrm{P} / \mathrm{B}$ ratio of 9 as often advocated (Gerlach 1971; Warwick and Price 1979; Bouvy 1988). Using a 10\% 426 factor for energy conversion efficiency (Bouvy 1988), a nematode carbon demand of 1.13 $427 \mathrm{ngC}$ ind $^{-1} \mathrm{~h}^{-1}$ can be calculated. In the present study, the maximum ingestion rate of bacteria measured would represent $4 \%$ of this energy demand. On the other hand, the maximum algal ingestion measured would correspond to $15 \%$ of this demand. To get $100 \%$ of their energy needs, nematodes may graze at a higher rate on the algal compartment, as discussed above. 431 Nematodes may also be dependent on other food sources such as detritus, protozoa, 432 oligochaetes or nematodes (Moens and Vincx 1997). The role of Dissolved Organic Matter in 433 nematode nutrition also remains elusive, although it is likely to be highly relevant (Lopez et al. 1979; Meyer-Reil and Faubel 1980; Montagna 1984a; Jensen 1987). Bacterial carbon was found to constitute $6 \%$ of the total carbon requirement of a mudflat nematode community 436 (van Oevelen et al. 2006b). On the other hand, using inverse modeling, Van Oevelen et al. 437 (2006c) suggested that mudflat community of nematodes relied for $50 \%$ on algae and $39 \%$ 438 on bacteria. Variations between studies can be due to differences in methodology and to 439 nematode community composition.

440 In the brouage mudflat, nematode present a mean densities of 2112 ind $10 \mathrm{~cm}^{-2}$ (Rzeznik441 Orignac et al. 2003) whereas biomasses of benthic bacteria represent $0.846 \mathrm{gC} \mathrm{m}^{-2}$ (Degré et 442 al. 2006). If nematodes grazing rates measured in the present study are representative of those 443 of total community, it would imply that $0.02 \%$ of bacterial biomass is assimilated by 444 nematodes each day. This extrapolation is debatable, as studied nematodes feed 445 predominantly on diatoms whereas total community may be more dependent on bacterial 446 resource, consequently grazing of bacteria is probably underestimated. 


\section{Conclusion}

448 Caution must be taken in interpreting our results, since the impact of each environmental

449 factor on the feeding behavior of the nematode community was studied separately, whereas in 450 natural environment all these factors covary greatly. The combination of temperature and 451 salinity factors was found to have a higher impact than each factor taken alone (Tietjen and 452 Lee 1972; Tietjen and Lee 1977). Moreover, nematodes may respond to environmental 453 changes at a seasonal scale, by physiological adjustment and shifting of their optimum 454 conditions (Gee 1985). However, the nematode community studied appeared to have adapted 455 to the highly variable environment constituted by the surficial sediment of intertidal mudflats, except at low temperatures $\left(5^{\circ} \mathrm{C}\right)$, and their feeding activity is only slightly decreased by

457 temperature, salinity or light stress. Due to high abundance of bacteria in the marine sediment, 458 nematodes may never be food limited with bacteria. Nematodes kept feeding under conditions 459 of stress which were typical of the surficial sediment habitat, moreover they appeared to be 460 principally dependent on the algal resource. Consequently, the community of nematodes 461 dwelling in the top centimeter of the Brouage mudflat may also have a feeding strategy which 462 is strongly linked to the formation of algal biofilm during the diurnal ebb.

\section{Acknowledgements}

464 We thank Prescilla Perrichon and Stéphanie Bollard for their help in sample preparation, 465 Gaël Guillou for isotopic analyses, Utte Wollenzien from NIOO-CEMO for giving us a $N$. 466 phyllepta strain and Janet Heard Carnot for English corrections. This work was financially 467 supported by the "Conseil Général de Charente Maritime", the ANR-VASIREMI and ECCO 468 and "PNEC Chantier Littoral Atlantique".

469 Experiments of the present study comply with current laws of French country. 


\section{References}

Boucher G (1974) Premières données écologiques sur les nématodes libres marins d'une station de vase côtière de Banyuls. Vie Milieu 23: 69-100

Bouvy M (1988) Contribution of the bacterial and microphytobenthic microflora in the energetic demand of the meiobenthos in an intertidal muddy sediment (Kerguelen Archipelago). P. S. N. Z. I: Mar Ecol 9: 109-122

Buffan-Dubau E, Carman KR (2000) Diel feeding behavior of meiofauna and their relationships with microalgal resources. Limnol Oceanogr 45: 381-395

Carman KR, Dobbs FC, Guckert JB (1989) Comparison of three techniques for administering radiolabeled substrates for trophic studies: uptakes of label by harpaticoid copepods. Mar Biol 102: 119-125

Chatterji A, Ansari ZA, Mishra JK, Parulekar AH (1995) Seasonality in meiofaunal distribution on a tropical beach at Balramgari, northwest coast of India. Indian J Mar Sci 24: 49-55

Croll NA (1970) The behaviour of nematodes: their activity, senses and responses. Edward Arnold, London

Decho AW (1988) How do harpaticoides grazing rates differ over a tidal cycle? Field verification using chlorophyll-pigment analyses. Mar Ecol Prog Ser 45: 263-270

Degré D, Leguerrier D, Armynot du Chatelet E, Rzeznik-Orignac J, Auguet J-C, Dupuy C, Marquis E, Fichet D, Struski C, Joyeux E, Sauriau P-G, Niquil N (2006) Comparative analysis of the food webs of two intertidal mudflats during two seasons using inverse modelling: Aiguillon Cove and Brouage Mudflat, France. Est Coast Shelf Sci 69: 107124

Duncan A, Schiemer F, Klekowski RZ (1974) A preliminary study of feeding rates on bacterial food by adult femals of a benthic nematode, Plectus palustris de Man 1880. Pol Arch Hydrobiol 21: 249-258

Fenchel T (1972) Aspects of decomposer food chains in marine benthos. Verh Dtsch Zool Ges 65: 14-22

Forster SJ (1998) Osmotic stress tolerance and osmoregulation of intertidal and subtidal nematodes. J Exp Mar Biol Ecol 224: 109-125

Gee JM (1985) Seasonal aspects of the relationship between temperature and respiration rate in four species of intertidal harpaticoid copepod. J Exp Mar Biol Ecol 93: 147-156

Gerlach SA (1971) On the importance of marine meiofauna for benthos communities. Oecologia 6: 176-190

Grewal PS, Wright RT (1992) Migration of Caenorhabditis elegans (Nematod: Rhaabditidae) larvae towards bacteria and the nature of bacterial stimulus. Fund Appl Nemat 15: $159-166$ 
Guarini JM, Blanchard GF, Gros P, Harrison SJ (1997) Modeling the mud surface temperature on intertidal flats to investigate the spatio-temporal dynamics of the benthic microalgal photosynthetic capacity. Mar Ecol Prog Ser 153: 25-36

Hamels I, Sabbe K, Muylaert K, Vyverman W (2004) Quantitative importance, composition, and seasonal dynamics of protozoan communities in polyhaline versus freshwater intertidal sediments Microb Ecol 47: 18-29

Heip CHR, Herman P, Coomans A (1982) The productivity of marine meiobenthos. Academia Analecta 44: 1-20

Heip CHR, Vincx M, Vranken G (1985) The ecology of marine nematodes. Oceanogr Mar Biol Annu Rev 23: 399-489

Héral M, Razet D, Deslous-Paoli JM, Bertome JP, Garnier J (1982) Caractéristiques saisonnières de l'hydrologies du complexe estuarien de Marennes-Oléron (France). Revue des travaux de l'institut des pêches maritimes 46: 97-119

Herlory O, Guarini JM, Richard P, Blanchard GF (2004) Microstructure of microphytobenthos biofilm and its spatio-temporal dynamics in an intertidal mudflat (Aiguillon Bay, France). Mar Ecol Prog Ser 282: 33-44

Herman PMJ, Vranken G (1988) Studies of the life history and energetics of marine and brackish water nematodes. II. Production, respiration and food-uptake by Monhystera disjuncta. Oecologia 77: 457-463

Holling CS (1959) Some characteristics of simple types of predation and parasistism. Canadian Entomologist 91: 385-398

Hondeveld BMJ, Bak RPM, van Duyl FC (1992) Bacterivory by heterotrophic nanoflagellates in marine sediments measured by uptake of fluorescently labeled bacteria. Mar Ecol Prog Ser 89: 63-71

Jensen KT (1987) Feeding ecology of free-living aquatic nematodes. Mar Ecol Prog Ser 35: 187-196

Kelly JA, Honeywill C, Paterson DM (2001) Microscale analysis of chlorophyll-a in cohesive intertidal sediments: the implications of microphytobenthos distribution. J Mar Biol Ass U K 81: 151-162

Kemp PF (1990) The fate of benthic bacterial production. Rev Aquat Sci 2: 109-124

Kuipers BR, de Wilde PAWJ, Creutzberg F (1981) Energy flow in a tidal flat ecosystem. Mar Ecol Prog Ser 5: 215-221

Legendre L, Rassoulzadegan F (1996) Food-web mediated export of biogenic carbon in oceans: hydrodynamic control. Mar Ecol Prog Ser 145: 179-193

Leguerrier D, Niquil N, Boileau N, Rzeznik J, Sauriau PG, Le Moine O, Bacher C (2003) Numerical analysis of the food web of an intertidal mudflat ecosystem on the Atlantic coast of France. Mar Ecol Prog Ser 246: 17-37 
Leguerrier D, Niquil N, Petiau A, Bodoy A (2004) Modeling the impact of oyster culture on a mudflat food web in Marennes-Oléron Bay (France). Mar Ecol Prog Ser 273: 147-162

Lopez G, Riemann F, Schrage M (1979) Feeding biology of the brackish-water Oncholaimid nematod Adoncholaimus thalassophygas. Mar Biol 54: 311-318

MacIntyre HL, Geider RJ, Miller DC (1996) Microphytobenthos: the ecological role of the "secret garden" of unvegetated, shallow-water marine habitats. I. Distribution, abundance and primary production. Estuaries 19: 186-201

Mariotti A (1982) Apports de la géochimie isotopique à la connaissance du cycle de l'azote. PhD Thesis, Paris, pp 476

Meyer-Reil LA, Faubel A (1980) Uptake of organic matter by meiofauna organisms and interrelationships with bacteria. Mar Ecol Prog Ser 3: 251-256

Moens T (1999) Feeding ecology of free-living estuarine nematodes. An experimental approach. PhD Thesis302

Moens T, Bergtold M, Traunspurger W (2006) Feeding ecology of free-living benthic nematodes. In: Eyulaem A, Andrassy I, Traunspurger W (eds) Freshwater nematodes: ecology and taxonomy. CAB International publishing, Cambridge, pp 105-131

Moens T, Herman P, Verbeeck L, M. S, Vincx M (2000) Predation rates and prey selectivity in two predacious estuarine nematode species. Mar Ecol Prog Ser 205: 185-193

Moens T, Verbeeck L, de Maeyer A, Swings J, Vincx M (1999a) Selective attraction of marine bacterivorous nematodes to their bacterial food. Mar Ecol Prog Ser 176: 165178

Moens T, Verbeeck L, Vincx M (1999b) Feeding biology of a predatory and a facultatively predatory nematode (Enoploides longispiculosus and Adoncholaimus fuscus). Mar Biol 134: 585-593

Moens T, Verbeeck L, Vincx M (1999c) Preservation and incubation time-induced bias in tracer-aided grazing studies on meiofauna. Mar Biol 133: 69-77

Moens T, Vierstraete A, Vincx M (1996) Life strategies in two bacterivorous marine nematods: preliminary results. P. S. N. Z. I: Mar Ecol 17: 509-518

Moens T, Vincx M (1997) Observations on the feeding ecology of estuarine nematodes. J Mar Biol Ass U K 77: 211-227

Moens T, Vincx M (2000) Temperature, salinity and food thresholds in two brackishwater bacterivorous nematode species: assessing niches from food absorption and respiration experiments. J Exp Mar Biol Ecol 243 137-154

Montagna PA (1984a) Competition for dissolved glucose between meiobenthos and sediment microbes. J Exp Mar Biol Ecol 76: 177-190

Montagna PA (1984b) In situ measurement of meiobenthic grazing rates on sediment bacteria and edaphic diatoms. Mar Ecol Prog Ser 18: 119-130 
Montagna PA (1995) Rates of metazoan meiofaunal microbivory: a review. Vie Milieu 45: 19

Montagna PA, Bauer JE (1988) Partitioning radiolabeled thymidine uptake by bacteria and meiofauna using metabolic blocks and poisons in benthic feeding studies. Mar Biol 98: $101-110$

Montagna PA, Blanchard GF, Dinet A (1995) Effect of production and biomass of intertidal microphytobenthos on meiofaunal grazing rates. J Exp Mar Biol Ecol 185: 149-165

Nicholas WL, Grassia A, Viswanathan S (1973) The efficiency with which Caenorhabditis briggsae (Rhabditinae) feeds on the bacterium Escherichia coli. Nematologica 19: 411-420

Nozais C, Desrosiers G, Gosselin M, Belzile C, Demers S (1999) Effect of ambient UVB radiation in a meiobenthic community of a tidal. Mar Ecol Prog Ser 189: 149-158

Pascal PY, Dupuy C, Mallet C, Richard P, Niquil N (2008) Bacterivory by benthic organism in sediment: quantification using- ${ }^{15} \mathrm{~N}$ enriched bacteria. J Exp Mar Biol Ecol 355: 1826

Pascal PY, Dupuy C, Richard P, Niquil N (In press) Bacterivory in the common foraminifer Ammonia tepida: isotope tracer experiment and the controlling factors. J Exp Mar Biol Ecol

Platt HM (1977) Vertical and horizontal distribution of free-living marine nematodes from Strangford Lough, Northern Ireland. Cah Biol Mar 18: 261-273

Platt HM, Warwick RM (1980) The significance of free-living nematodes to the littoral ecosystem. In: Price JH, Irvine DEG, Farnham WF (eds) The shore environment, Vol 2. Academis Press, London and New-York, pp 729-759

Riera P, Richard P, Grémare A, Blanchard GF (1996) Food source of intertidal nematods in the Bay of Marennes-Oléron (France), as determined by dual stable isotope analysis. Mar Ecol Prog Ser 142: 303-309

Rivkin RB, Legendre L, Deibel D, Tremblay JE, Klein B, Crocker K, Roy S, Silverberg N, Lovejoy C, Mesplé F, Romero N, Anderson MR, Matthews P, Savenkoff C, Vézina AF, Therriault JC, Wesson J, Bérubé C, Ingram RG (1996) Vertical flux of biogenic carbon in the ocean: Is there food web control? Science 272: 1163-1166

Romeyn K, Bouwman L (1983) Food selection and consumption by estuarine nematodes. Hydrobiol Bull 17: 103-109

Rzeznik-Orignac J, Fichet D, Boucher G (2003) Spatio-temporal structure of the nematode assemblages of the Brouage mudflat (Marennes Oléron, France). Est Coast Shelf Sci 58: $77-88$

Sander BC, Kalff J (1993) Factors controlling bacterial production in marine and freshwater sediments. Microb Ecol 26: 79-99 
Schiemer F (1982a) Food dependence and energetics of freeliving nematodes. I. Respiration, growth and reproduction of Caenorhabditis briggsae (Nematoda) at different levels of food supply. Oecologia 54: 108-121

Schiemer F (1982b) Food dependence and energetics of freeliving nematodes. II. life history parameters of Caenorhabditis briggsae (Nematoda) at different levels of food supply. Oecologia 54: 122-128

Schiemer F (1983) Comparative aspects of food dependance and energetics of free living nematodes. Oikos 41: 32-42

Schiemer F (1987) Nematoda. In: Pandian TJ, Vernberg FJ (eds) Animal energetic. Academic Press, New York, pp 185-211

Schiemer F, Duncan A, Klekowski RZ (1980) A bioenergetic study of a benthic nematod, Plectus palustris de Man 1880, throughout its life style. II Growth, fecundity and energy budget at different levels of bacterial food and general ecological considerations. Oecologia 44: 205-212

Schmidt JL, Deming JW, Jumars PA, Keil RG (1998) Constancy of bacterial abundance in surficial marine sediments. Limnol Oceanogr 43: 976-982

Serôdio J, da Silva JM, Catarino F (1997) Nondestructive tracing of migratory rhythms of intertidal benthic microalgae using in vivo chlorophyll a fluorescence. J Phycol 33: $542-553$

Soetaert K, Vincx M, Wittoeck J, Tulkens M (1995) Meiobenthic distribution and nematode community structure in five European estuaries. Hydrobiologia 311: 185-206

Somerfield PJ, Warwick RM, Moens T (2005) Methods for the study of marine benthos. In: Eleftheriou A, McIntyre AD (eds) Meiofauna techniques. Blackwell Science, Oxford, pp 229-272

Steyaert M, Herman PMJ, Moens T, Widdows J, Vincx M (2001) Tidal migration of nematodes of an estuarine tidal flat (the Molenplaat, Schelde Estuary, SW Netherlands). Mar Ecol Prog Ser 224: 299-304

Steyaert M, Vanaverbeke J, Vanreusel A, Barranguet C, Lucas C, Vincx M (2003) The importance of fine-scale, vertical profiles in characterizing nematode community structure. Est Coast Shelf Sci 58: 353-366

Sundbäck K, Nilsson C, Odmark S, Wulff A (1996a) Does ambient UV-B radiation influence marine diatom-dominated microbial mats? A case study. Aquat Microb Ecol 11: 151159

Sundbäck K, Nilsson P, Nilsson C, Jonsson B (1996b) Balance between autotrophic and heterotrophic components and processes in microbenthic communities of sandy sediments: a field study. Est Coast Shelf Sci 43: 689-706

Taghon GL, Self RLF, Jumars PA (1978) Predicting particle selection by deposit feeders: a model an its implications. Limnol Oceanogr 23: 752-759 
Thomas JH (1989) Genetic analysis of defecation in Caenorhabditis elegans. Genetics 124: $855-872$

Tietjen JH (1980) Microbial-meiofaunal interrelationships: a review. Microbiology 110: 335338

Tietjen JH, Lee JJ (1972) Life cycles of marine nematodes. Influence of temperature and salinity on the development of Monhystera denticulata Timm. Oecologia 10: 167-176

Tietjen JH, Lee JJ (1973) Life history and feeding habits of the marine nematode Chromadora macrolaimoides Steiner. Oecologia 12: 303-314

Tietjen JH, Lee JJ (1977) Life histories of marine nematodes. Influence of temperature and salinity on the reproductive potential of Chromadorine germanica Bütschli. Mikrofauna Meeresboden 61: 263-270

Tietjen JH, Lee JJ, Rullman J, Greengart A, Trompeter J (1970) Gnotobiotic culture and culture physiological ecology of the marine nematode Rhabditis marina Bastian. Limnol Oceanogr 15: 535-543

Underwood GJC, Kromkamp JC (2000) Primary production by phytoplancton and microphytoplancton in estuaries. In: Nedwell DB, Raffaelli DG (eds) Estuaries, Advances in Ecological Research. Academic Press, pp 93-153

van Oevelen D, Middelburg JJ, Soetaert K, Moodley L (2006a) The fate of bacterial carbon in sediments: modeling an in situ isotope tracer experiment. Limnol Oceanogr 51: 13021314

van Oevelen D, Moodley L, Soetaert K, Middelburg JJ (2006b) The trophic significance of bacterial carbon in a marine intertidal sediment: Results of an in situ stable isotope labeling study. Limnol Oceanogr 51: 2349-2359

van Oevelen D, Soetaert K, Middelburg JJ, Herman PMJ, Moodley L, Hamels I, Moens T, Heip CHR (2006c) Carbon flows through a benthic food web: integrating biomass, isotope and tracer data. J Mar Res 64: 453-482

Vranken G, Herman PMJ, Heip CHR (1988) Studies of the life history and energetics of marine and brackish-water nematodes I. Demography of Monhystera disjuncta at different temperature and feeding conditions Oecologia 77: 296-301

Warwick RM, Price JH (1979) Ecological and metabolic studies on freeliving nematodes from an estuarine mudflat. Est Coast Mar Sci 9: 257-271

Wieser W (1953) Die Beziehungen zwischen Mundhölengestalt, Ernährungsweise und Vorkommen bei freilebenden marinen nematoden. Ein ökologisch-morphhlogische studie. Arkiv fur Zoologi 4: 439-484

Wieser W (1960) Benthic studies in Buzzards Bay. II. The meiofauna. Limnol Oceanogr 5: $121-137$ 
694 Table and Figures captions

695

696 Table 1. List of species ranked by dominance (feeding types according to Wieser (1953;

697 1960)). 1A: selective deposit feeders; 1B: non-selective deposit feeders; 2A: epigrowth

698 feeders; 2B: omnivores/predators.

699 Table 2. Nematodes isotopic composition $\left(\Delta^{15} \mathrm{~N}\right.$ and $\Delta{ }^{13} \mathrm{C}$ mean $\left.\pm \mathrm{SD}, \mathrm{N}=3\right)$ and bacterial 700 and algal uptake rates calculated.

701 Figure 1. Map of the study site.

702 Figure 2. Assimilation of bacterial carbon (mean $\pm \mathrm{SD}, \mathrm{N}=3$ ) as function of incubation time 703 (h).

704 Figure 3. Assimilation rate of bacterial carbon (mean $\pm \mathrm{SD}, \mathrm{N}=3$ ) as function of temperature $705\left({ }^{\circ} \mathrm{C}\right)$. Different letters above bars indicate significant differences between incubation 706 conditions (ANOVA; Tukey test).

707 Figure 4. Assimilation rate of bacterial carbon (mean \pm SD) as function of bacterial 708 abundance $\left(10^{8}\right.$ cell. $\left.\mathrm{ml}^{-1}\right)$. Different letters above bars indicate significant differences between 709 incubation conditions (ANOVA; Tukey test).

710 Figure 5. Assimilation rate of bacterial carbon (mean \pm SD) as function of algal abundance $711 \quad\left(\mu g C h l a . g^{-1}\right)$.

712 Figure 6. Uptake rate of algal carbon $\bigcirc$ (mean \pm SD) and bacterial carbon $\bigcirc$ (mean \pm SD) as 713 function of algal abundance $\left(\mu \mathrm{gChla} \mathrm{g}^{-1}\right)$. Bacterial abundance was constant $\left(10.5 \times 10^{8}\right.$ cells $\left.714 \mathrm{ml}^{-1}\right)$. 


\section{Table}

Table 1

\begin{tabular}{lcc} 
Genera species & Feeding type & Abundance relative (\%) \\
\hline Chromadora macrolaima & 2A & 64.2 \\
Daptonema oxycerca & 1B & 15.2 \\
Ptycholaimellus jacobi & 2A & 7.9 \\
Sabatieria pulchra & 1B & 2.6 \\
Axonolaimus paraspinosus & 1B & 1.7 \\
Praeacanthonchus punctatus & 2A & 1.7 \\
Halalaimus sp. & 1A & 1.0 \\
Aegialoalaimus sp. & 1A & 1.0 \\
Sphaerolaimus gracilis & 2B & 0.7 \\
Spilophorella sp. & 2A & 0.7 \\
Metachromadora sp. & 2A & 0.7 \\
Theristus sp. & 1B & 0.3 \\
Parodontophora marina & 1B & 0.3 \\
Tripyloides marinus & 1B & 0.3 \\
Eleutherolaimus sp. & 1B & 0.3 \\
Desmolaimus zeelandicus & 1B & 0.3 \\
Daptonema hirsutum & 1B & 0.3 \\
Terschellingia sp. & 1A & 0.3 \\
Viscosia sp. & 2B & 0.3
\end{tabular}


Table 2

\begin{tabular}{|c|c|c|c|c|c|c|}
\hline \multirow{3}{*}{ Kinetics (hours) } & \multicolumn{2}{|c|}{$\Delta^{15} N$} & \multirow{2}{*}{$\begin{array}{c}\text { Bacteria uptake } \\
\left(\text { pg C ind }^{-1} h^{-1}\right)\end{array}$} & \multicolumn{2}{|c|}{$\Lambda^{13} \mathrm{C}$} & \multirow{2}{*}{$\begin{array}{r}\text { Algae uptake } \\
\left({\left.\text { pg } C \text { ind }^{-1} h^{-1}\right)}\right.\end{array}$} \\
\hline & Control & Normal & & Control & Normal & \\
\hline & & & & & & \\
\hline 1 & & $12.01 \pm 0.25$ & $3.67 \pm 4.06$ & & & \\
\hline 2 & & $14.24 \pm 0.86$ & $20.00 \pm 7.03$ & & & \\
\hline 3 & $11.78 \pm 0.23$ & $15.20 \pm 0.38$ & $18.51 \pm 2.05$ & $-15.4 \pm 1.32$ & & \\
\hline 5 & & $20.63 \pm 1.49$ & $28.80 \pm 4.84$ & & & \\
\hline 8 & & $27.72 \pm 1.55$ & $32.41 \pm 3.15$ & & & \\
\hline 12 & $11.56 \pm 0.87$ & $32.66 \pm 4.91$ & $28.31 \pm 6.65$ & $-15.8 \pm 0.77$ & & \\
\hline \multicolumn{7}{|l|}{ Temperature $\left({ }^{\circ} \mathbf{C}\right)$} \\
\hline 5 & & $12.41 \pm 0.53$ & $3.38 \pm 2.87$ & & & \\
\hline 10 & & $14.60 \pm 0.50$ & $15.26 \pm 2.70$ & & & \\
\hline 30 & & $16.38 \pm 0.79$ & $24.92 \pm 4.27$ & & & \\
\hline 40 & & $15.18 \pm 1.73$ & $18.42 \pm 9.38$ & & & \\
\hline \multicolumn{7}{|l|}{ Irradiance } \\
\hline Light & & $19.42 \pm 2.01$ & $41.43 \pm 10.88$ & & & \\
\hline \multicolumn{7}{|l|}{ Salinity } \\
\hline 18 & & $15.03 \pm 0.66$ & $17.62 \pm 3.57$ & & & \\
\hline \multicolumn{7}{|l|}{$\begin{array}{l}\text { Bacterial abundance } \\
\left(10^{8} \text { cells } \text { wt sed }^{-1}\right)\end{array}$} \\
\hline 4.2 & & $11.75 \pm 0.20$ & $-0.65 \pm 4.39$ & & & \\
\hline 7.0 & & $12.25 \pm 0.40$ & $3.34 \pm 2.93$ & & & \\
\hline 17.4 & & $15.86 \pm 0.10$ & $18.34 \pm 0.45$ & & & \\
\hline \multicolumn{7}{|l|}{$\begin{array}{l}\text { Algal abundance } \\
(\mu \mathrm{g} \text { Chla g dry sed } \\
\end{array}$} \\
\hline 25.6 & & $15.39 \pm 0.59$ & $19.58 \pm 3.19$ & & $-4.44 \pm 6.53$ & $\mathbf{5 8 . 9 4} \pm \mathbf{3 2 . 3 5}$ \\
\hline 64.3 & & $15.58 \pm 0.51$ & $20.59 \pm 2.78$ & & $25.60 \pm 4.79$ & $107.11 \pm 12.24$ \\
\hline 113.7 & $11.50 \pm 0.17$ & $14.34 \pm 0.61$ & $13.87 \pm 3.33$ & $-16.34 \pm 0.53$ & $52.14 \pm 33.29$ & $161.20 \pm 78.30$ \\
\hline
\end{tabular}




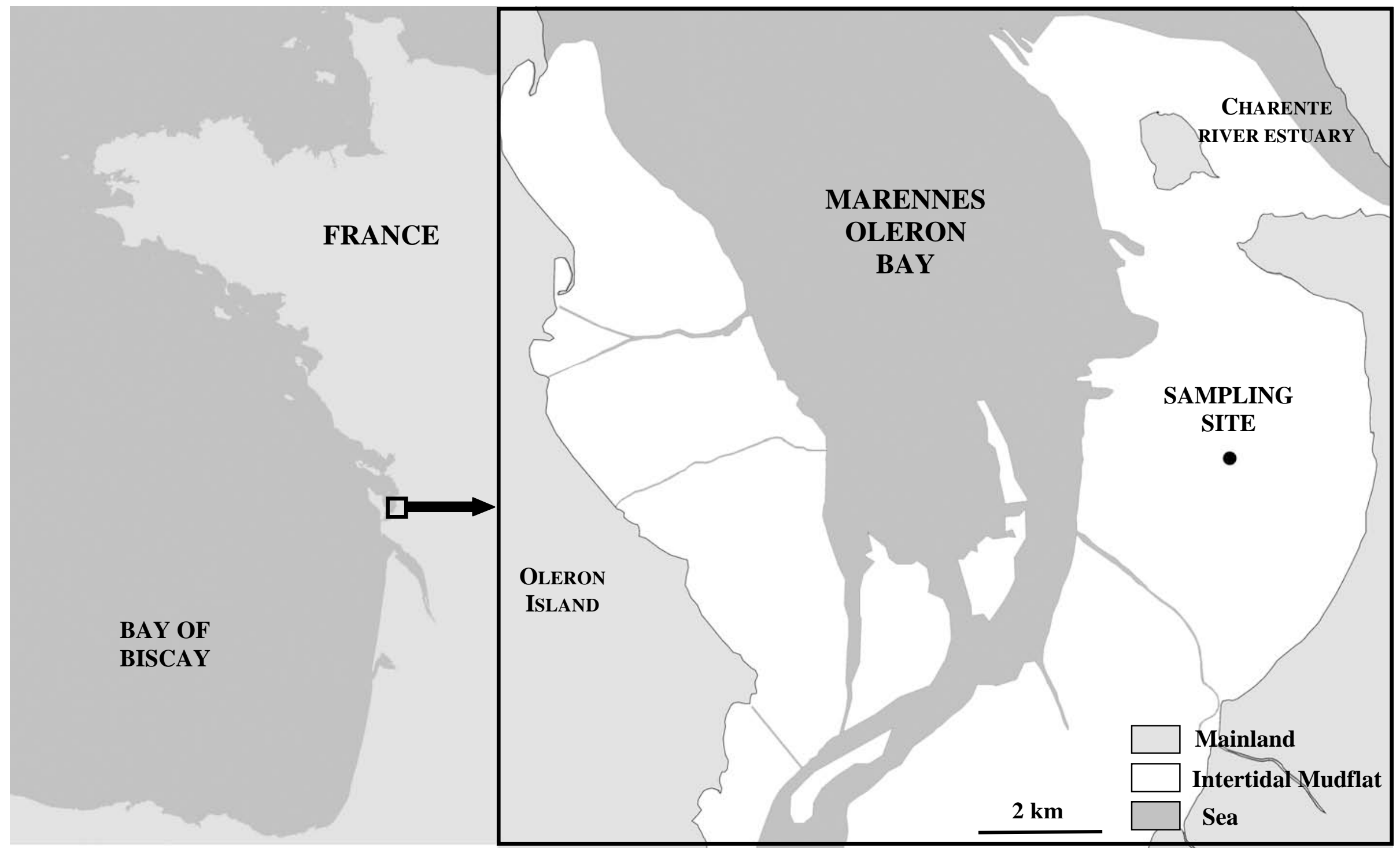

Fig. 1 


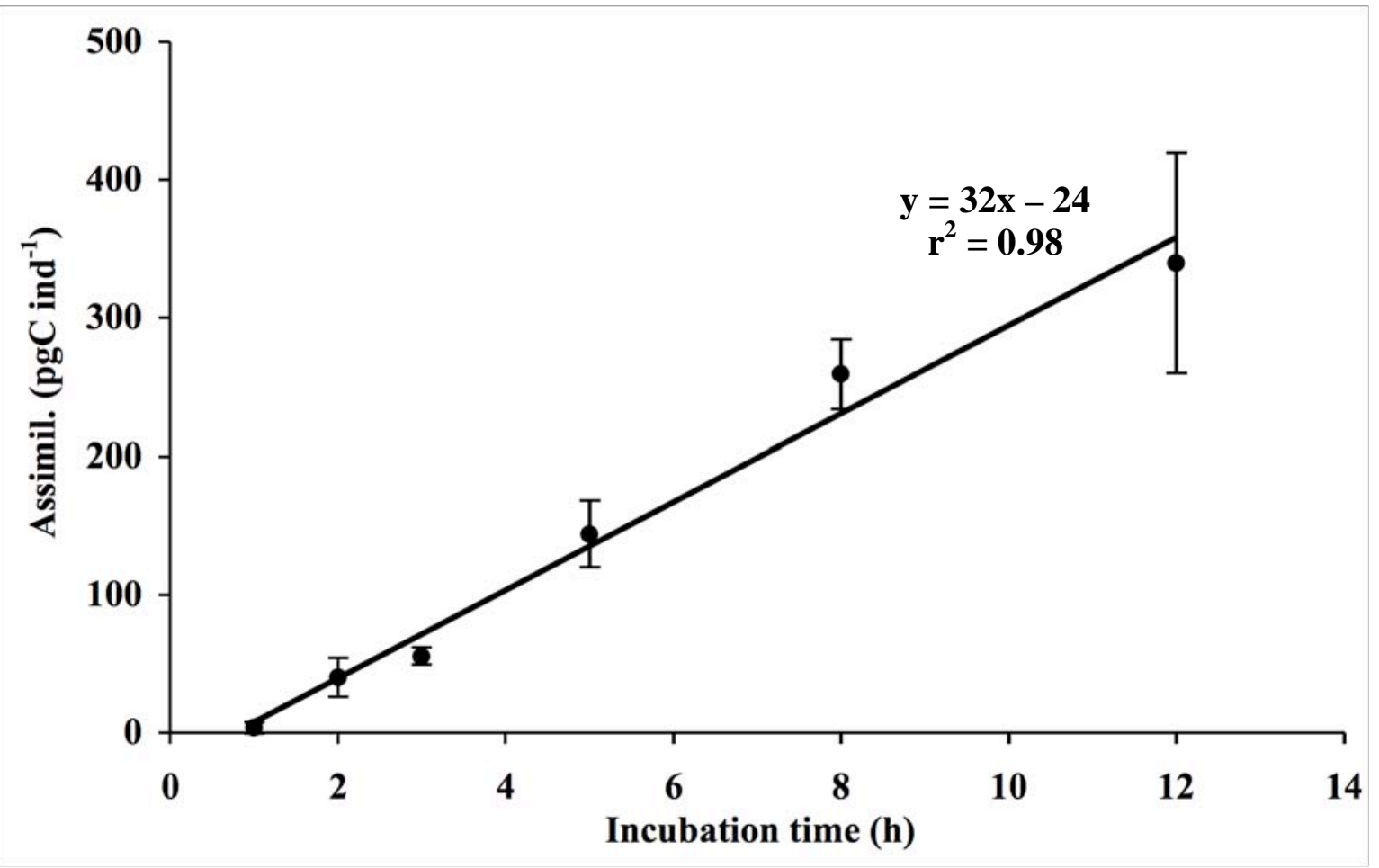

Fig. 2

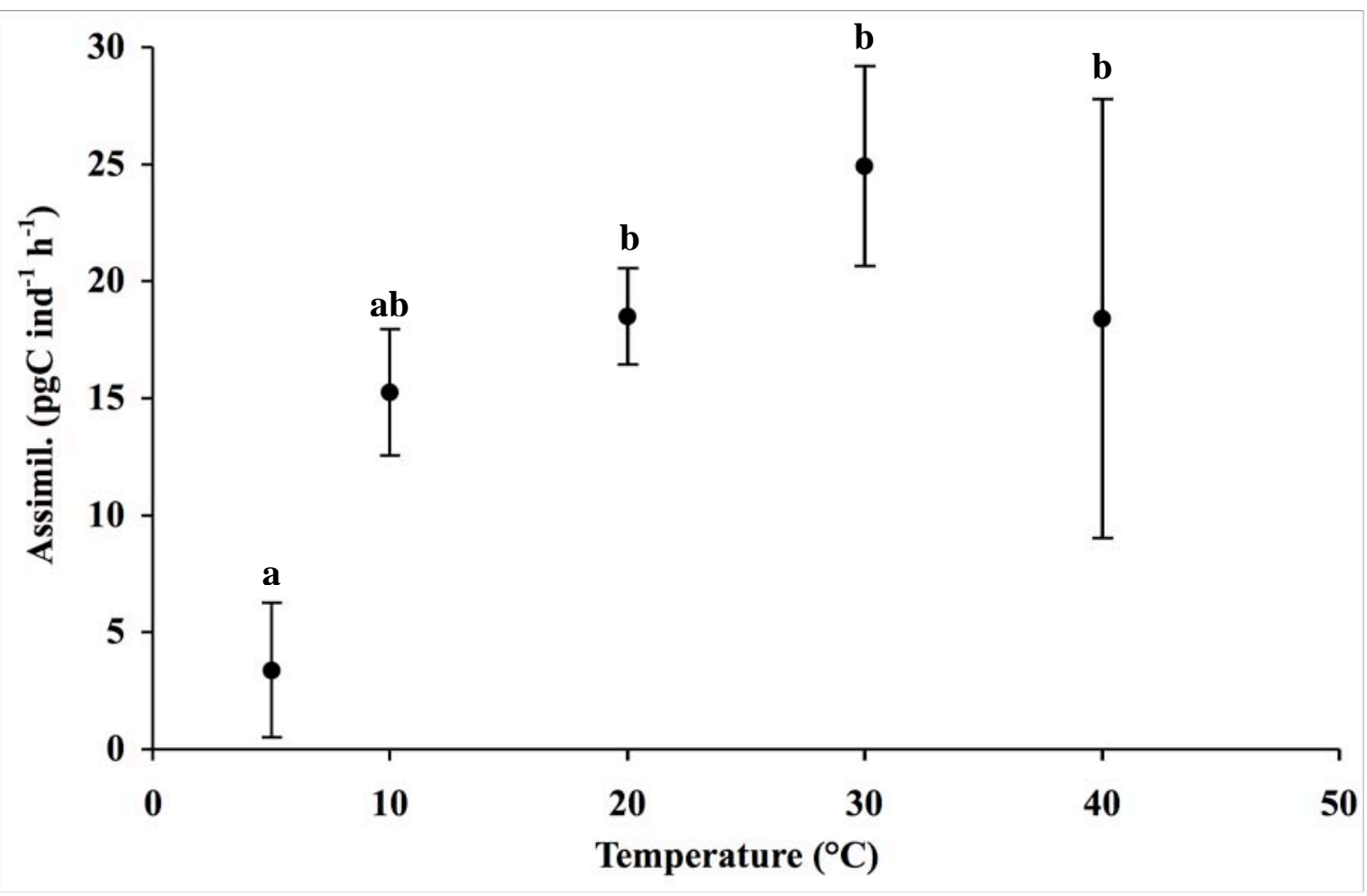

Fig. 3 


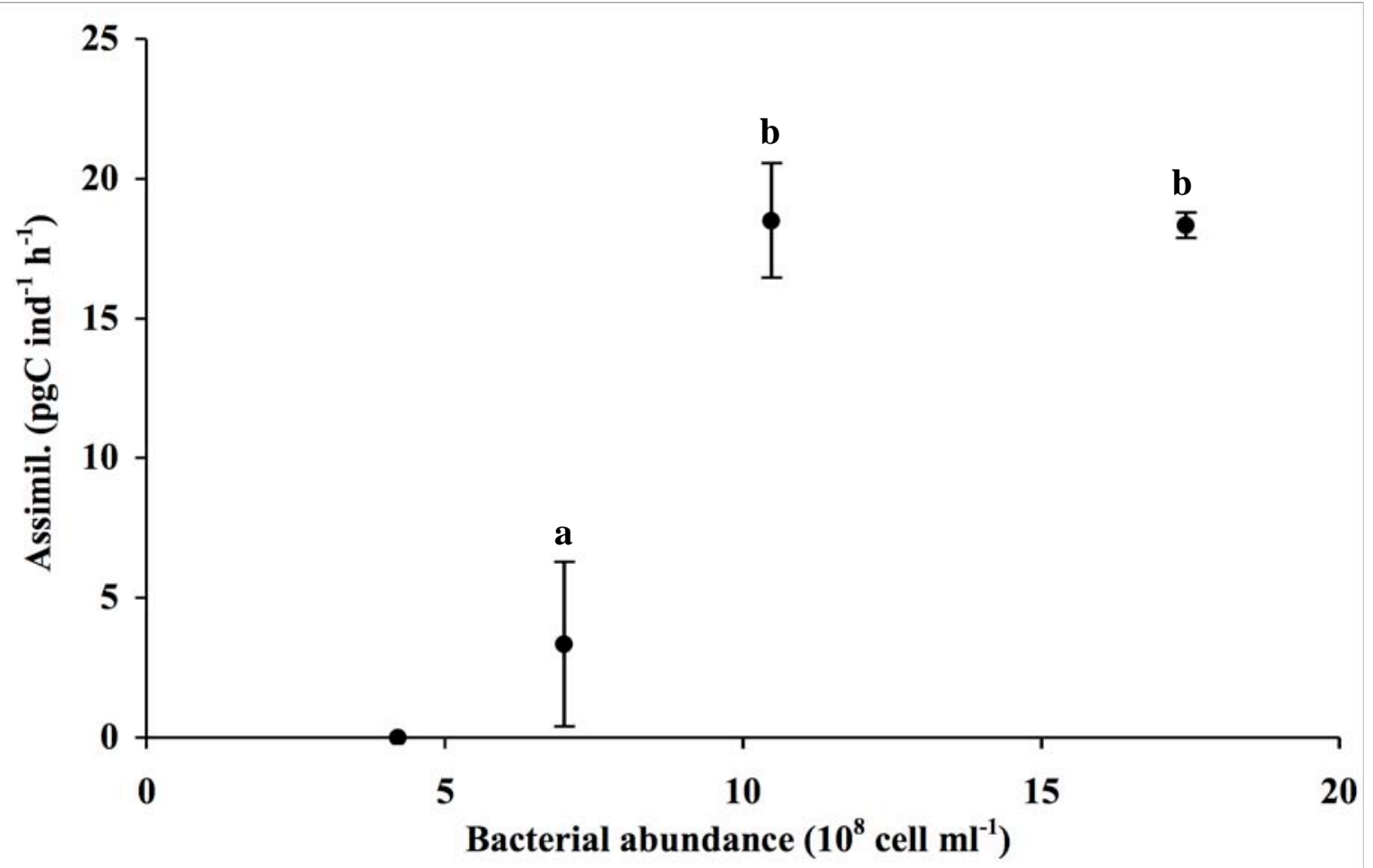

Fig. 4

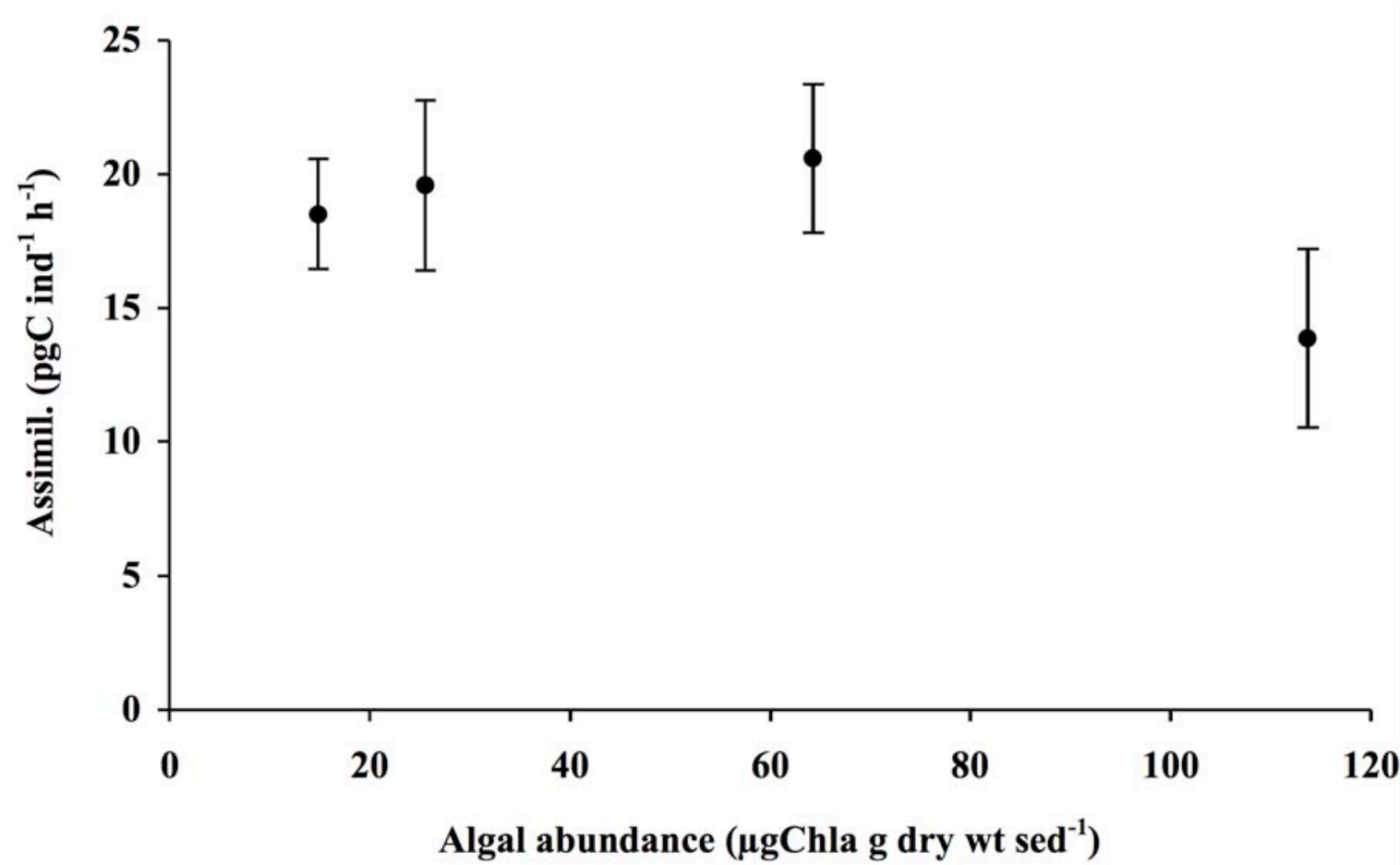

Fig. 5 


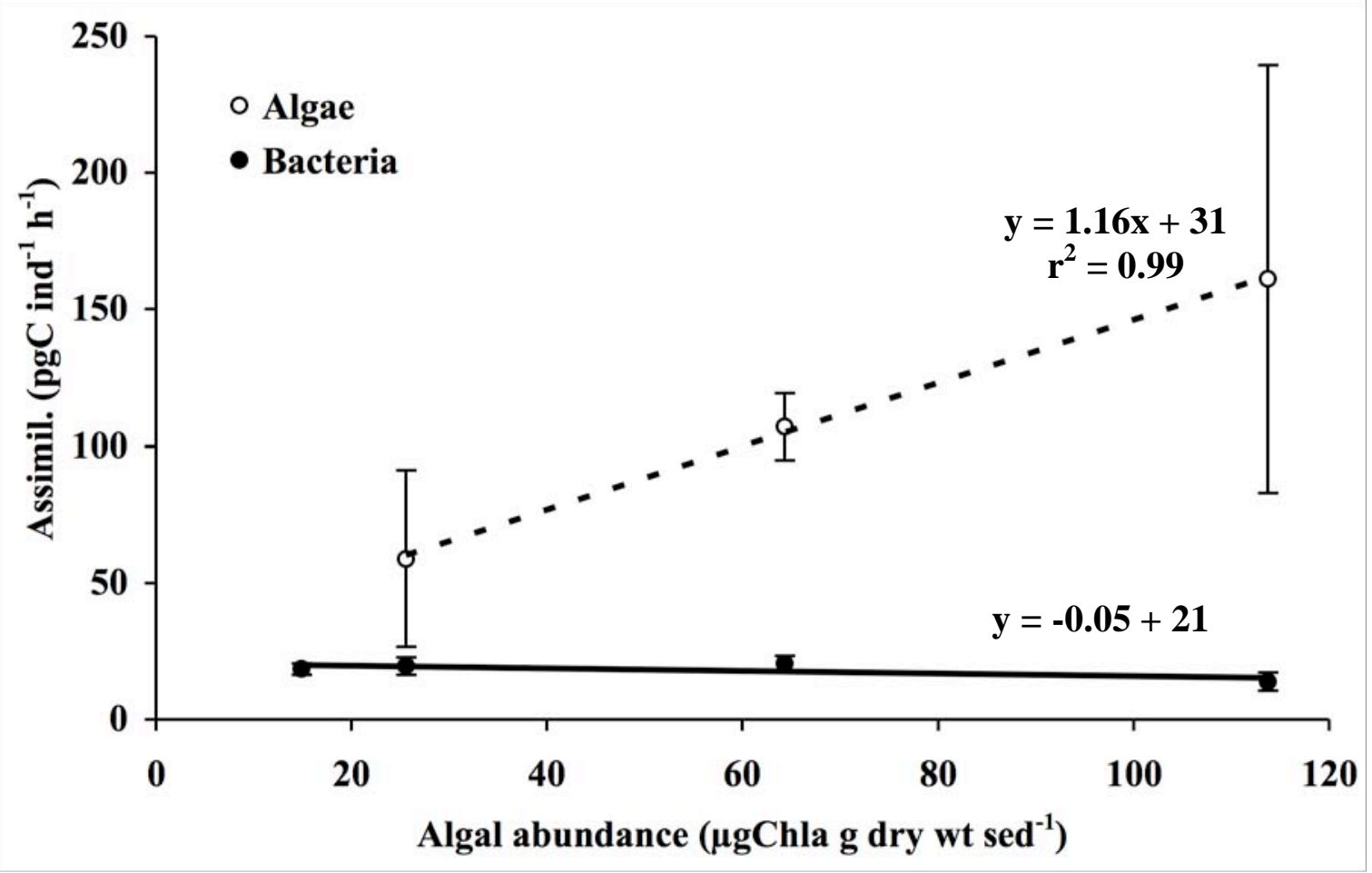

Fig. 6 